The University of Southern Mississippi

The Aquila Digital Community

Faculty Publications

$5-1-2012$

\title{
The Nation Before Taste: The Challenges of American Culinary History
}

Andrew P. Haley

University of Southern Mississippi, andrew.haley@usm.edu

Follow this and additional works at: https://aquila.usm.edu/fac_pubs

Part of the United States History Commons

\section{Recommended Citation}

Haley, A. P. (2012). The Nation Before Taste: The Challenges of American Culinary History. Public Historian, 34(2), 53-78.

Available at: https://aquila.usm.edu/fac_pubs/210

This Article is brought to you for free and open access by The Aquila Digital Community. It has been accepted for inclusion in Faculty Publications by an authorized administrator of The Aquila Digital Community. For more information, please contact Joshua.Cromwell@usm.edu. 


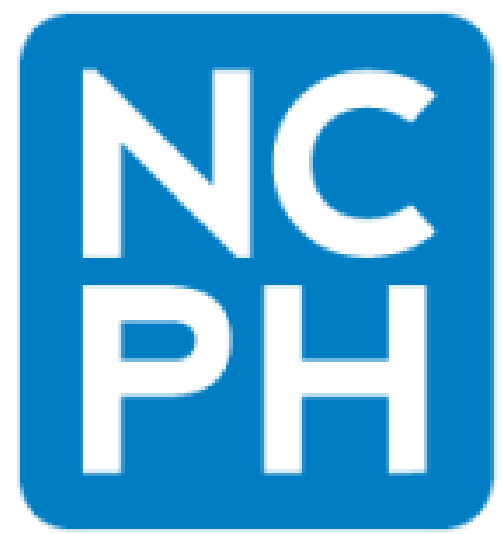

The Nation before Taste: The Challenges of American Culinary History Author(s): Andrew P. Haley

Source: The Public Historian, Vol. 34, No. 2 (Spring 2012), pp. 53-78

Published by: University of California Press on behalf of the National Council on Public History

Stable URL: http://www.jstor.org/stable/10.1525/tph.2012.34.2.53

Accessed: 17-10-2016 21:40 UTC

JSTOR is a not-for-profit service that helps scholars, researchers, and students discover, use, and build upon a wide range of content in a trusted digital archive. We use information technology and tools to increase productivity and facilitate new forms of scholarship. For more information about JSTOR, please contact support@jstor.org.

Your use of the JSTOR archive indicates your acceptance of the Terms \& Conditions of Use, available at http://about.jstor.org/terms

National Council on Public History, University of California Press are collaborating with JSTOR to digitize, preserve and extend access to The Public Historian 


\title{
The Nation before Taste: The Challenges of American Culinary History
}

\author{
ANDREW P. Haley
}

\begin{abstract}
Food is material and familiar, and because it is, we are often overconfident about our ability to understand the culinary past. It is easy to believe that if we can discover the recipe for some forgotten dish, the history of the dish becomes intelligible. When it does not, it tempts those who consume culinary history to impose modern sensibilities on our predecessors. "The Nation before Taste" argues that historians and museum curators must be especially vigilant when presenting the history of food. Reviewing a series of historical challenges that stemmed from studying the United States in the late nineteenth and early twentieth centuries, the author suggests three strategies for grounding food history in the past: recognizing that taste is constructed and temporal; engaging with material and social contexts, especially physiology, class, and gender; and admitting to our audiences that not all culinary mysteries have immediate or simple answers.
\end{abstract}

Key words: taste, culinary history, Gilded Age and Progressive Era, physiology, class, gender, chop suey

FOR THE MODERN HISTORICAL WAYFARER browsing the food section at Barnes \& Noble, visiting the Julia Child kitchen at the Smithsonian, or stumbling across a dusty collection of recipes in the attic, America's culinary past is often shrouded in myth. Culinary memory invokes images of a grandmotherly woman in an apron guarding pies cooling in the window or a slightly ridiculous French chef in a floppy hat hopping from pot to pot to taste the

The Public Historian, Vol. 34, No. 2, pp. 53-78 (May 2012).

ISSN: 0272-3433, electronic ISSN 1533-8576.

(C) 2012 by The Regents of the University of California and the

National Council on Public History. All rights reserved.

Please direct all requests for permission to photocopy or reproduce article content through the University of California Press's Rights and Permissions Web site: www.ucpressjournals.com/reprintInfo.asp. DOI: 10/1525/tph.2012.34.2.53. 
soup. We embrace these sentimentalized versions of our ancestors not only because we want our culinary history to serve as comfort food, but also because these nickel-plated versions of the past serve as convenient foils for our times. Today, we have embraced food adventurism as a sign of machismo and a source of weekly entertainment (think New York's Gastronauts or $357 \mathrm{Mad}$ Dog Hot Sauce or nearly every other episode of Survivor). ${ }^{1}$ While not all of us seek out the thrill of eating live squid and squirming bugs, we nonetheless rely on the contrast between our own spirit of adventure and our image of grandma in her kitchen to sustain our belief that this generation-our generation-has ushered in a culinary renaissance.

For those of us who seek to interest the public in culinary history, both authors and curators, the thrall of food is a blessing and a curse. Invariably, and perhaps understandably, when I talk about culinary history I find that my audience is often more interested in the food than the history. They want to know what the past tasted like and, it seems, are less interested in the ways in which food's centrality offers the potential of unlocking historical "truths." Food is tangible and ostensibly reproducible, and the survival of our species demands that we care about it. But this fascination with the object of our study poses unique challenges for the interpreter, for in the absence of a strong historical narrative, our imaginations take flight and what we remember is the object and not the object lesson. I recently attended the much ballyhooed "What's Cooking, Uncle Sam?" exhibit at the National Archives in Washington, D.C. The exhibit drew on a rich record of government policy concerning food, but, perhaps, in its effort to shy away from a triumphalist account of food regulation, it offered the visitor no master narrative, no clear story about either the significance of government regulation or changing ideas about food. For me, as for others, it was LBJ's barbeque recipe that left the most lasting impression. ${ }^{2}$

Synthesizing over two hundred years of food history is a formidable challenge, and the National Archives' failure was not singular. ${ }^{3}$ In this essay, a personal reflection on the challenges of doing culinary history, I want to consider the source of our romance with food and the challenges inherent in making culinary history understandable. It is a first attempt to come to terms with the complexity of understanding sensory history, particularly taste, as socially and temporally constructed. ${ }^{4} \mathrm{I}$ believe that thinking through these issues has

1. Morewenna Ferrier, "Macho foodies in New York develop a taste for notoriety," The $\mathrm{Ob}$ server, May 30, 2010, http://www.guardian.co.uk/lifeandstyle/2010/may/30/food-restaurantsmacho-eating-live (accessed December 2010).

2. Alice D. Kamps, What's Cooking Uncle Sam? The Government's Effect on the American Diet (Washington, DC: Foundation for the National Archives, 2011), 90.

3. Instead of citing the failures of particular authors, I have tried to focus on key issues that both writers and curators who consider food need to address. For a more thorough review of the field, see (especially the contribution by Jeffrey Pilcher) Andrew Smith, Jeffrey M. Pilcher, and Darra Goldstein, "Food Scholarship and Food Writing," Food, Culture \& Society 13, no. 3 (September, 2010): 319-29.

4. Work on the history of taste is underway. The most substantial contribution to date was made by Carolyn Korsmeyer in Making Sense of Taste (Ithaca, NY: Cornell University Press, 1999). Although historically informed, Korsmeyer has written a work of philosophy and generally ad- 
important implications for how we present our culinary history to a public that is increasingly willing to gobble up all that we can offer. My fear is that as culinary history proliferates, we may be tempted to serve up dishes halfbaked, where the absence of a strong historical narrative rooted in both sensitivity to the nuances of the past and the limits of our knowledge may allow nostalgia to run roughshod over substance.

\section{Cooking Up the Past}

Our myths, if not always our history, portray Americans as go-getters and risk takers. Our stories celebrate the pioneers who conquered a continent, the engineers who dammed rivers, and the architects who built skyscrapersand contemporary chefs have claimed a place in that pantheon. If our modern accomplishments - competitions to see how many hot dogs we can stuff down our gullets in twelve minutes - seem a little pathetic in contrast to what our forefathers and foremothers did, there is no denying that we live in a golden age of culinary delights. Our grocery stores and farmers' markets offer up an unprecedented variety of raw ingredients, and our twenty-four-hour seven-day-a-week cooking channels are never short on suggestions for new dishes. Yes, our age has its critics — apologists for grandma and her butter-rich pies and environmentalists concerned about our wastefulness - but, ironically, the Jeremiahs only serve to reinforce our need to believe that Anthony Bourdain's No Reservations is paving new ground.

Yet this celebration of our own golden age of cooking poses challenges for American food historians, in no small part because it replaces two hundred years of messy, contested history with a calcified and condescending vision of a sentimentalized past, easily understood and even more easily dismissed. Today, cookbook after cookbook and almost every food program on the history channel supposes that our culinary heritage is fully intelligible and that with a little patience, the recipes of our past can be located and reproduced. That is not true, and our failure to grasp that our culinary heritage must be thoroughly, carefully, and painstakingly contextualized (and even then it may not be fully accessible) runs the risk of undermining not only culinary history but all our efforts to develop a history of the nonvisual senses.

I do not think we can cook up the past. While it is certainly true that food memories are powerful and food evokes nostalgia, it is impossible to recapture the past completely, and the sooner we recognize this as historians, the

dresses the idea and aesthetic of taste, rather than its social history. Mark M. Smith in Sensing the Past (Berkeley, CA: University of California Press, 2007), in contrast, has developed the scaffolding on which to build a history of taste, but at times conflates the history of the socially constructed sense of taste with a more general history of food and eating. Finally, although not specifically about physical taste, Susanne Freidberg's Fresh: A Perishable History (Cambridge, MA: Harvard University Press, 2009) offers a compelling look at the potential value of studying what occurs when the meanings attributed to food change. 
better off we are. It is no more possible to recreate an apple pie from the midnineteenth century than it is to know exactly what was going through the mind of Abraham Lincoln as he walked up to the platform to give the Gettysburg Address. Yet in the first instance, we persist in believing that a complete understanding of the past is perfectly attainable, and in the second, historians largely agree that our understanding of the past is never complete.

Our hubris is understandable. Unlike Lincoln's private thoughts, food is public, material, and seemingly reproducible. We have, after all, carefully catalogued countless cookbooks, culinary magazines, and menus that seem to hold the keys to unlocking our culinary heritage. Why is it that we cannot recover an early recipe for apple pie, bake it up, and experience a little bit of history?

An apple pie is more than a recipe; it is the ingredients, the mixing and baking, and the gustatory experience. Each of these poses a problem for the modern culinary wayfarer who wants to understand the history of food. The most obvious problem is that ingredients change. As environmental historians know, John Chapman-Johnny Appleseed-sold apple trees that no longer exist. These heritage varieties were lost to time and to national markets that demanded apples that could be stored for long periods and shipped across the continent. Less obvious, but no less significant, we do not make pies the way we once did. How can we truly reproduce the old kitchenware, the wood and coal-fired ovens, the bacteria-laden, unventilated spaces, the inexact measurements, and the adulterated ingredients? How can we cook with abandon knowing that cholesterol causes heart disease? Why would we test the temperature of a stove with bits of paper when we have cheap thermometers or use lard when we have Crisco? 5

And even if we could make an apple pie exactly as our great, great, great grandmother made her apple pie, could we experience it the way she did? We may be able to approximate the aesthetic experience in much the way that symphonies, using period instruments, sometimes try to recapture the aesthetics of Bach, but that is not history. Merely recreating the recipe is not the same as understanding how that pie was consumed and what it meant to those who dined a hundred years ago. The pie may be material and roughly reproducible, but the meaning attached to the pie is fleeting. It is constructed by a whole set of life experiences and social contexts. It is a product of xenophobia and sentimentality, science and economics, and structures of feeling. A pie is never just a pie.

Historians in the past fifty years have become increasingly aware that describing the past is not the same as understanding the past. Cultural history, with its emphasis on constructed meaning and its distrust of the explicit evidentiary record, was at first lampooned and then broadly embraced. It is difficult these days to find a serious work of history that does not borrow, at least in small ways, from the lessons of postmodernism, literary theory, and cul-

5. Amy Barnes, Cooking School Recipes (Northhampton, MA: Gazette Printing Company, 1893), introduction. 
tural anthropology. Culinary history, although rooted in social history and women's history with their emphasis on understanding everyday lives, owes much to the cultural historian's commitment to understanding not only how material goods were produced, but also how they were consumed, and the meanings people attached to them.

Works that have now become classic, from Laura Shapiro's Perfection Salad to Harvey Levenstein's Revolution at the Table to Donna Gabaccia's We Are What We Eat, emphasized both production and consumption. ${ }^{6}$ While crazy recipes, innovative cookware, and newly discovered vegetables made regular appearances in these tales of the past, their focus was always on the reasons why people transformed raw ingredients into complex dinners and the meanings they attached to the feasting that followed. In subsequent years, food history has occasionally seemed as if it has regressed. Although it is important that we continue to catalog taxonomies of ingredients and iconic dishes, we need to go beyond description and address the tricky questions that surround meaning. I fear, as the public appetite for culinary history continues to grow, that the insatiable demand for more stories will overwhelm the field with works that do little more than tantalize our taste buds.

Understanding the historical role of food requires that we confront the point at which the private and the public meet, the point at which biology, economics, sentiment, and nascent ideologies are baked into the apple pie, and the ways in which these ingredients are understood when the pie is eaten. These challenges are not simple, nor are they unique to food history, as Drew Gilpin Faust's recent observations about the difficulties of telling war stories makes clear, but unless we are fully cognizant of the limits of our ability to know the past and clear about our purpose, nostalgia will distort the culinary historian's enterprise. ${ }^{7}$

What follows is personal and specific; it is drawn from my research into the history of the food in the United States at the end of the nineteenth century and the start of the twentieth century. It is my grappling with the challenges of not only understanding the historical importance of food but also communicating that story to students and readers. Ultimately, I believe that culinary history offers us meaningful insights into how people thought about themselves and how they related to their bodies, to each other, and to their politics. My reflection on the difficulty of understanding the history of eating begins with a central problem that I think often clouds our understanding of the culinary past: taste matters more today than it ever has.

6. Laura Shapiro, Perfection Salad: Women and Cooking at the Turn of the Century (New York: Farrar Straus and Giroux, 1986); Harvey A. Levenstein, Revolution at the Table: The Transformation of the American Diet (New York: Oxford University Press, 1988); Donna Gabaccia, We Are What We Eat: Ethnic Food and the Making of Americans (Cambridge, MA: Harvard University Press, 2000).

7. Drew Gilpin Faust, “Telling War Stories: Reflections of a Civil War Historian,” lecture, Jefferson Lecture in the Humanities, National Endowment for the Humanities, Washington, DC, May 2, 2011, http:/www.neh.gov/news/humanities/2011-05/TellingWarStoriesWeb.pdf (accessed December 2011). 


\section{A Dearth of Taste}

A few years ago I was asked to consult on a series of dinners intended to recreate, in every detail, dining as it would have happened a hundred years ago. The galas were held at a resort in South Carolina, and everything from the servers' uniforms to the table decorations was reproduced with an eye to historical accuracy. Compromises were made, of course, but in most respects these dinners were true to the past, except for one aspect: the food. I submitted recipes and reports and met repeatedly with the chef, but in the end, he knew that sugar sculptures and forcemeat encased in a thick layer of glistening aspic were unacceptable at a modern-day dinner party. We compromised, and the end product-a historical fusion cuisine - was delicious. These events, however, made clear to me the differences between how Americans thought about food in the past and how we think of food today. We locate prestige in taste, a personal, socially constructed, and constantly renegotiated sense of what is good and what is not. ${ }^{8}$ We read restaurant reviews in the local newspaper, consult Yelp and Urbanspoon on our cell phones, and take pictures of our food to post on Facebook. Our culinary predecessors, at least the ones I study in the late nineteenth and early twentieth centuries, did not. The value of the dinner for them was measured in the abundance of dishes, the quality of the conversation at the table, and the social status of the guests. ${ }^{9}$ We think about taste; they, when they thought about the meal at all, thought about pedigree.

The first major guide to eating in New York was published in 1903. Where and How to Dine in New York is, in some ways, typical of how Americans understood food before the rise of the middle-class restaurant at the turn of the twentieth century. Dozens of primarily upper-class restaurants are described in intricate detail, including who can be seen there (upper-class fashionables,

8. Josée Johnston and Shyon Baumann, "Democracy versus Distinction: A Study of Omnivorousness in Gourmet Food Writing," American Journal of Sociology 113, no. 1 (2007): 165-204. My purpose in this essay is not philosophical, but historical. However, my assumptions are that gustatory sensations alone are not "taste." Instead, "taste" emerges as we develop a language to describe, negotiate, and access those physical sensations.

9. This is not to say that no one cared about the food or that they did not use the word "taste" in their own historically specific way. Hosts and hostesses of dinner parties took great pride in designing a menu that stimulated the appetite and extended the meal, ensuring that the guests remained at table for a longer period of time so that diners had ample opportunity to engage in conversation. However, the rules set out for those planning a dinner emphasized simple contrasts that do not correspond to our modern ideas of taste or menu planning. Menus, they believed, should balance fish versus meat, hot versus cold, and even various colors, and when they did address sensory taste it seldom rose above discussions of rich versus plain foods. This remained true through the 1920s and 1930s. Emily Post's Etiquette, first published in 1922, included over fifty pages on giving a formal dinner but dedicated only two for the menu. Post opposed an unvarying meal of white sauces or sweet dishes. Even if "each dish is good in itself," she wrote, it would be "unappetizing in the monotony of its combination." All of which may be true, but as a guide for pairing flavors (and recognizing subtleties of taste), it is severely lacking. Emily Post, Etiquette: The Blue Book of Social Usage (New York: Funk \& Wagnalls Company, 1937), 188-89. 
Broadway fashionables, or political fashionables) and where the best artwork in each establishment is located. But describing the food served at these restaurants was an afterthought, almost entirely ignored. Take the description of the Café Boulevard, a French and Hungarian restaurant whose somewhat exotic cuisine would seem to have required a little explanation. Instead of a discussion of the goulash, however, we are told that President Roosevelt was known to dine there, we are regaled with tales of the mahogany doors and marble mantels, and we are offered a detailed study of a statue called "Devil in Chains." 10 The food was noted but the account was minimal: "The cuisine of the Cafe is especially Hungarian, that is, Hungarian dishes may be had but the place is as much French as Hungarian. Among the special dishes for which it is famous are 'paprika chicken' and 'porkolt." Only two sentences, in a fourpage review, are given over to the culinary offerings, and what made these dishes notable to the anonymous author is not that they tasted good but rather that they made the restaurant "famous." This entry is not exceptional. The report of the food at the Hotel Vendome in New York was a little more extensive, but entrées and service were still given less attention than the guests and the architecture, and the menu was described in generic terms. "The cuisine of the Vendome is as excellent as all the best facilities make possible," we are told, and "certain dishes are selected by a great many guests as representative of the chef's best manner."11 Yet this brief reference to "excellent" dishes makes no mention of taste. The chef's skill is commended and the fine facilities are praised, but the author lacks a language of taste to describe the dishes and to explain to potential diners why any particular dish on the menu should be preferred over others.

In its general lack of gustatory detail, Where and How to Dine in New York is emblematic of culinary sources from the nineteenth and early twentieth centuries. As I set out to study food, I initially turned to memoirs and travelogues, expecting them to be full of everyday accounts of dining in public at the turn of the century. Not so. In journal after journal, I found that food got scant attention. We can see this clearly in the diaries of American author and journalist Theodore Dreiser.

Dreiser's journals are frustrating in their lack of detail about what he ate. Consider his references to dining in a rather long entry from Saturday, October 27, 1917: "We go to the Koster Glocke. A fair meal. Conversation excellent. Literature, the war, New York publishers, American newspapers, etc."12 Dreiser is living in Greenwich Village in 1917, a time when the Village is a center of cultural and culinary innovation and Dreiser, who rarely seems to cook for himself, ate out a lot. Yet he says little of interest about what it was

10. Where and How to Dine in New York: The Principal Hotels, Restaurants and Cafes of Various Kinds and Nationalities Which Have Added to the Gastronomic Fame of New York and Its Suburbs (New York: Lewis, Scribner, 1903), 206-09.

11. Where and How to Dine in New York, 73-75.

12. Theodore Dreiser, American Diaries, 1902-1926, ed. Thomas P. Riggio, James L. W. West and Neda M. Westlake (Philadelphia: University of Pennsylvania Press, 1982), 196. 
that he was eating. On Friday, November 9, 1917, he writes: "Decide to go to Hotel Endicott, then to a vaudeville show at Riverside (96th and Broadway). Lovely night. We have a fair meal." ${ }^{3}$ Granted, his repeated use of the term "fair meal" implies some sense of judgment, but he lacks the language or the inclination to elaborate on what he means by "fair," and for that matter, what constitutes a meal. Nor is he any more garrulous when he moves to the West Coast. On Friday, July 9, 1920, he notes: "Get cake, blackberries \& a ham sandwich for Helen \& come home." ${ }^{4}$ On Wednesday, April 27, 1921: "Then to Hazelwood for breakfast. Eggs 20 cent a dozen but a chicken liver omelette [sic] is still 65. ${ }^{\text {cts. }}$ "15 On Sunday, June 26, 1921: "We breakfast late."16 And this goes on and on and on in a detailed daily diary. While the journal at times provides insightful comment on politics and social issues, every meal is either fair or excellent and ingredients, costs, and companionship get more attention than the food itself.

Yet, even if Dreiser thought little about how his food tasted, he was, nonetheless, a gifted observer of the social importance of dining. In Sister Carrie, restaurants are instrumental in both Carrie's fall from grace and eventual rise to influence. In the following passage, Carrie is taken to a fine-dining establishment for the first time by Charles Drouet, a traveling salesman who will soon set her up in an apartment and make her a kept woman.

"Now," he said, getting Carrie and himself comfortably settled, "what will you have?"

Carrie looked over the large bill of fare which the waiter handed her without really considering it. She was very hungry, and the things she saw there awakened her desires, but the high prices held her attention. "Half broiled spring chicken—seventy-five. Sirloin steak with mushrooms — one twenty-five." She had dimly heard of these things, but it seemed strange to be called to order from the list. ${ }^{17}$

Here, Dreiser captures differences of gender and class in a succinct and nuanced way. Carrie's poverty is demonstrated by her hunger and her obsession with price; Drouet's privilege — as both a man and a man about town — is symbolized by his ability to order steak and asparagus. The path of the novel is immediately apparent. Carrie cannot rise to be an independent woman until she acquires the financial and cultural capital that men, even men of the middling class, possess.

Dreiser understood that a good meal was laden with meaning. He understood that food signified class and embodied gender relations. However, he did not dwell on these heady ideas daily and, equally importantly, in both the

13. Dreiser, American Diaries, 202.

14. Dreiser, American Diaries, 327.

15. Dreiser, American Diaries, 355.

16. Dreiser, American Diaries, 321.

17. Theodore Dreiser, Sister Carrie (Champaign, IL: Project Gutenberg, 2004), http://www .gutenberg.org/files/5267/5267-h/5267-h.htm (accessed April 2011). 
novels and the diaries, he gave little attention to how food tasted. In fact, the diaries imply, he spent considerably less time thinking about taste than he spent procuring ingredients for friends willing to cook his dinner. On a daily basis, food was practical and social, but it was not sensual. I can't say I have read every entry in every volume of Dreiser's diaries but I have read extensively and I have not come across a single detailed description of how the food he ate tasted. In this regard, the diaries are very similar to Where and How to Dine, and neither work is unusual for the time. Charlotte Perkins Gillman called for the establishment of communal dining rooms, but while she distinguishes between a "gorgeous dinner" and a "good lunch" in her diaries, she does not explain the difference. ${ }^{18}$ Charles Chesnutt transformed a stereotype about African Americans' love of chicken into a scathing indictment of racism, but his account of visiting Washington in his youth (although filled with complaints about railroad cars) scarcely mentions food. ${ }^{19}$ Likewise, John Dos Passos writes about a "delightful souper sur l'herbe" he participated in on a hillside as a child, but it was the sunset that accrued all the adjectives and not the cold roast chicken, cheeses, or jellies. ${ }^{20}$

This cavalier approach to food was not merely the blindness we develop toward everyday events. Visitors to the United States, many of whom felt it incumbent upon themselves to discuss the food they encountered, rarely discussed taste - at least not in terms we would find familiar. G. W. Steevens, a reporter for London's Daily Mail, visited the United States in 1897 and dedicated a chapter of his travelogue to food, but beyond his surprise at the prevalence of ice water, the similarities between fried eggplant and fried egg, and William Jennings Bryan's prodigious appetite, he is notably vague about what it was that he liked or disliked about American food. ${ }^{21}$ He found the steaks "insipid," the fish "weak," and the blue-point oysters "rich with . . flavour," but these banalities are nothing more than simple comparisons. For Steevens, everything was rated as more flavorful or less than its British counterpart, an account of American dining that pales in comparison to the debate about where to find the best hot dogs in Chicago that is taking place on websites like Chowhound even as you read this article. In fact, having read thousands of turn-of-the-century magazine and newspaper articles written by both Americans and foreign visitors about the food of the United States, I cannot recall a single one that gets close to approaching the discussion of taste found in almost any article on food plucked from the pages of Gourmet or Bon Appetit. Even Auguste Escoffier, the great French chef, had little to say about

18. Charlotte Perkins Gilman, The Diaries of Charlotte Perkins Gilman, ed. Denise D. Knight (Charlottesville: University Press of Virginia, 1994), 2: 433, 431.

19. Charles W. Chestnutt, The Journals of Charles W. Chestnutt, ed. Richard H. Bordhead (Durham: Duke University Press, 1993), 108-19.

20. John Dos Passos, The Fourteenth Chronicle: Letters and Diaries of John Dos Passos, ed. Townsend Ludington (Boston: Gambit Incorporated, 1973), 37.

21. G. W. Steevens, The Land of the Dollar (New York: Dodd, Mead, and Company, 1897), 281-82, 176-84. 
flavor, seasoning, or taste when questioned during a visit to New York in 1908. He admired America’s "soft clams" and expressed optimism that American cuisine would improve as Americans became more familiar with European standards, but he said nothing very specific about how food on either side of the Atlantic tasted. ${ }^{22}$

This lack of culinary curiosity offers a stark contrast with today. We obsess about food. We have multiple cooking channels and a host of culinary magazines dedicated to making the ordinary act of eating into a wondrous experience that invigorates the senses. When we discuss where to go to dinner, we habitually begin with a catalog of ethnicities (German or American), then a discussion of food type (bar food or something healthy), and then a debate about specific restaurants with, perhaps, some mention of the cost, location, service, and atmosphere. I have gone to meals where the conversation about where to dine took longer than the meal and the evaluation of the dinner afterwards was longer still. This may be good; after all, we have to eat, and we might as well enjoy it, but our current romance with food poses challenges for those who wish to introduce the American public to the foodways of the past. Our ancestors did not share our fascination with food and our obsession with taste; or, perhaps more accurately, they had not yet developed a language of taste with which to describe the foods they ate. Before Emeril Lagasse and Rachel Ray, there was no "Bam" and no "Yum-o."

Keep in mind, the examples I have offered come from the American culinary class, urban members of the upper and middle classes who had the luxury of eating out regularly, a rather exceptional experience at the turn of the twentieth century. Most Americans, especially those in the working class, did not have these varied experiences and were even less likely to develop a complex vocabulary for describing food than their well-heeled countrymen. While the presence of multiple recipes for the same dish in some cookbooks might be viewed as evidence that middle-class and working-class Americans preferred one dish to another, diaries of both urban and rural Americans provide little evidence that taste determined how they ate. ${ }^{23}$ Most working-class Americans, and many middle-class Americans, consumed the same foods day after day and did so without acutely feeling that they wanted for variety. Carrie, after all, does not fully understand her deprivations until she is taken to dinner by Drouet. For large numbers of Americans into the twentieth century, putting food on the table was more important than developing a lexicon to describe it.

None of this means that those who lived prior to the twentieth century, rich or poor, did not discriminate between what was desirable and what was undesirable when it came to food. As Harvey Levenstein demonstrated, im-

22. "What M. Escoffier Found to Praise in America." New York Times, May 3, 1908.

23. Diary, "Diary," Mary Chaffee, January to December 1887, Schlesinger Library, Radcliffe College, Harvard University; Diary, Angeline Williams, 1886, 1902-1904, Schlesinger Library, Radcliffe College, Harvard University. 
migrants resisted the efforts of Boston's culinary reformers when they tried to encourage working-class families to eat cheaper cuts of meat in the late nineteenth century. ${ }^{24}$ Likewise, middle-class progressives at the turn of the century, supported by government scientists like Harvey Wiley, successfully lobbied for laws to combat food adulteration by citing both issues of health and flavor. But Americans lacked a taxonomy of taste that could value subtleties of flavor, even at a time when the French were well on their way to developing the language of modern dining. At least until the 1920s, and for many Americans not until after World War II, a good meal was judged by standards dictated by physiology, economy, race, and gender. ${ }^{25}$

Even America's most committed gastronomes were far from developing a way of talking about food as sophisticated as ours. As music editor for the New York Evening Post, Henry T. Finck was well steeped in the reviewer's art of criticism when he turned his attention to the culinary arts in 1913. The book he wrote, Food and Flavor, is one of the nation's first extended treatments of the gustatory senses. Finck, having examined German and American research on nutrition and having read the most important French works on cuisine, believed that the "most important problem now before the American public is to learn to enjoy the pleasure of the table and to insist on having savory food at every meal." 26 Yet Finck viewed "taste" as little more than the palatability of quality ingredients. He wrote eloquently about the abundance of American agriculture, husbandry, hunting, and fishing, but there is nothing in his seminal treatise that would help the judges at an Iron Chef America completion chose a winner between two well-trained chefs using the same high-quality ingredients. ${ }^{27}$ While Finck and his contemporaries started a conversation about food in America that would eventually lead to Craig Claiborne's star ratings, the era of discriminating restaurant reviews was still a long way off. ${ }^{28}$

24. Harvey Levenstein, Revolution at the Table, 52.

25. French gourmands, among them Jean Anthelme Brillat-Savarin, sought to develop a phys iology of taste and certainly did much to promote the idea that food could be "agreeable" or "dis agreeable." But read Savarin's Physiology of Taste and despite its ambitions, it still is essentially a treatise on the physicality of taste right down to arguing that certain people are more likely to appreciate culinary flavors than others. Nonetheless, Grimod de la Reynière, Brillat-Savarin, and those French gastronomes who followed were considerably further along than other nationals in developing gastronomy into a cultural field. Jean Anthelme Brillat-Savarin, Physiology of Taste; or, Transcendental Gastronomy, trans. Fayette Robinson (Philadelphia: Lindsay \& Blakiston, 1854); Priscilla Parkhurst Ferguson, "A Cultural Field in the Making: Gastronomy in Nineteenthcentury France," in Accounting for Taste: The Triumph of French Cuisine, ed. Priscilla Parkhurst Ferguson (Chicago: University of Chicago Press, 2004), 5-50.

26. Henry T. Finck, Food and Flavor: A Gastronomic Guide to Health and Good Living (New York: The Century Company, 1913), 42. Emphasis in original.

27. Discussions of ingredients and unique preparations do not preclude discussions of taste, and certainly when Americans bragged about New England chowder or Maryland turtles, they intended those discussions to imply some degree of taste discrimination. But that is very different from our modern sense of taste that assumes that you can-Iron Chef fashion-provide everyone with the same ingredients and they will nonetheless make a dish that can be judged better than another.

28. Mitchell Davis, "A Taste for New York: Restaurant Reviews, Food Discourse, and The Field of Gastronomy in America” (PhD diss., New York University, 2009), 98-99. 
Our ancestors' lack of a language of taste poses challenges for historians and museum curators who seek to introduce the modern omnivore to the recipes of the past. We can imagine their world, but it is not our own, and the act of taking the modern diner back to the past requires careful interpretation and a thorough historical context. Most importantly, it requires that the modern historical investigator-amateur or professional_-check her fundamental ideas about food at the door of the museum. All historians must guard against presentism, but it is especially important to do so when discussing something as visceral as food. We must impress upon our audiences that our concerns with historical context, economic status, and issues of race and gender are not trickery — the bait and switch of the historian who draws her audience to the table with promises of apple pie and serves up lectures on nationalism instead-but rather a genuine reflection of what those in the past thought about their larder.

Our job as historians is to assist with that historical journey, and we can only do so if we take seriously the ways in which people in the past (in this case, fin-de-siècle America) understood their bodies and their society. As such, any investigation must start with physiology and then consider how societal relations (in my examples, class and gender) shaped historical understandings of food. Yet, as I will demonstrate later in this essay, even a thorough understanding of the context may not offer all the answers to questions about why we ate the way we did. The greatest risk, and my motivation for writing this essay, is that we will offer up our culinary past to our audience even when we do not have a ready argument, because when we do that with food history, the temptation to substitute empathy for analysis is ever present.

\section{Food in Context}

\section{Physiology}

The Girl's Own Indoor Book, published in Philadelphia in 1888, observed that the ideal temperature of the human body was ninety-eight degrees and then recommended a diet high in fat, oil, starch, and sugar. "These substances, as their composition may indicate, are the heat-giving constituents of our food. . . " "29 Such advice was routine and, given the way Americans understood their bodies at the time, sound. But consider the implications. Measured by these guidelines, Elizabeth Ellicott Lea's recipe for making pie crusts in her Baltimore cookbook from 1869 was not only potentially delicious but also relatively healthy. "ONE pound of lard to a gallon of flour will make very good common pies. . . [W] hen you have put in the fruit, wet the crust with water,

29. Charles Peters, ed., The Girl's Own Indoor Book: Containing Practical Help to Girls on All Matters Relating to their Material Comfort and Moral Well-being (Philadelphia: J.B. Lippincott, 1888), 393. 
put on the top and close it up; stick it with a fork on the top."30 Lea intended that the pie be baked, but better yet, pan fry the pie (a technique not unheard of in nineteenth-century America) and you have a dish that sounds frighteningly like a McDonalds' apple pie and yet in the nineteenth century was considered wholesome.

Our fundamental notions of why we eat and what we should eat have changed. Until the end of the eighteenth century, many Americans' idea of what constituted healthy eating was still shaped by ancient Greek philosophical treatises on humors and food. This view of food maintained that there were four types of comestibles, wet, dry, hot, and cold, and that various food combinations were necessary to keep our body's fluids (biles, blood, and phlegm) in proper working order. Eating these culinary combinations in correct portions was necessary not only to maintain good health (in a sense that bears only a fleeting comparison with how we understand fitness today), but also to maintain a proper demeanor. Too much hot and the animal passions might get the best of you, but too much cold and your phlegm might rise precipitously, endangering your well-being and rendering you a cold fish. ${ }^{31}$

While the experts' certainty about the legitimacy of a biological science based on humors started to fade as early as the mid-eighteenth century, the link between food and disposition lingered. Despite advances in experimental science and a better understanding of the human body, belief in the physicality of mood and manner found adherents in America throughout the nineteenth century. Food reformers like Sylvester Graham, James Salisbury, and John Harvey Kellogg, although grounding their thinking in more sophisticated science than their predecessors, all believed that diet led to mental illness and sexual excess. Even the scientific revolution that followed Darwin's publication of On the Origins of the Species in 1859, despite its emphasis on scientific observation rather than philosophical musing, did not fully dislodge widespread beliefs that food created character. Followers of social Darwinism, applying a thin veneer of science, held that preferences for various foods were linked to class, ethnicity, and race. Thus, for the inheritors of the ancient Greeks' theories on humors, the nineteenth-century physiologists, and the advocates of social Darwinism, what a people ate potentially shaped their entire civilization. It is with this context in mind that we might best understand the fear and foreboding that that native-born Americans experienced when they first ventured into ethnic neighborhoods and tasted German, Italian, Chinese, Syrian, and Japanese food.

As the end of the nineteenth and start of the twentieth centuries, middleclass Americans amused themselves by going "slumming." They set out in car-

30. Elizabeth Ellicott Lea, Domestic Cookery, Useful Receipts, and Hints to Young Housekeepers (Baltimore: Cushings and Bailey, 1869), http://digital.lib.msu.edu/projects/cookbooks/ $\mathrm{html} /$ books/book_27.cfm (accessed January 2011). Emphasis in original.

31. This description of the very complex history of humors is brief. For a much fuller treatment, see Trudy Eden, The Early American Table: Food and Society in the New World (DeKalb: Northern Illinois University Press, 2008). 
riages, and later cars, to ethnic enclaves where they explored strange alleyways full of street vendors, took in vaudeville shows racier than those in their own neighborhoods, visited unfamiliar houses of worship and opium dens, and, almost invariably, experienced new foods. ${ }^{32}$ These adventures, including the culinary experiments, were always filled with a sense of trepidation. "Slummers" worried, whether they acknowledged it or not, that the exotic foods they sampled in ethnic neighborhoods might undermine their own civilized demeanors. Eat too much garlic and you might slip down the evolutionary ladder a rung or two. Of course, not everyone held such a simplistic idea of food and civilization, but most believed that preferences for certain foods were hereditary and that cultivated Americans would naturally prefer French food to Mexican.

Something akin to this type of racial logic is evident in an anonymous account of an urban adventurer's first visit to a German restaurant in 1901. Like other diners in major cities and small towns who ventured into ethnic restaurants to try chop suey, wiener schnitzel, Italian spaghetti, and other unfamiliar concoctions, he struggled with his preconceived ideas about the food he was about to eat and the culture that produced these unfamiliar dishes. In an article that first appeared in the Milwaukee Sentinel, he recalled the tense moment when he overcame his fear, got past the alien smells, and sampled a bite of German food for the first time.

So with an inward prayer to the special little god that watches over your health and well-being you sample, timidly and hopelessly, the dainty [the waitress] holds out to you on the tip of a fork. The fear vanishes and something akin to joy fills your soul, for you have experienced a distinctly new gustatory sensation. It may or may not be pleasing. The joy in the sensation lies in its novelty. ${ }^{33}$

For these culinary adventurers, fear and pleasure were intricately linked. Consuming new foods forced the middle-class diner to confront preconceived ideas about race and biology that were increasingly being challenged by new scientific research, but were nonetheless still deeply imbedded in the national psyche. It forced the urban adventurer to begin a complicated process of replacing long-held notions about the essential nature of food with the more flexible idea that taste was a matter of individual preference and culinary pleasure. And, in the twentieth century, it would undermine the hegemony of French food, usher in the era of restaurant reviews, and turn dining into a never-ending series of fads.

32. For more on slumming, see Chad Heap, Shumming: Sexual and Racial Encounters in the American Nightlife, 1885-1940 (Chicago: University of Chicago Press, 2009).

33. Reprinted from the Milwaukee Sentinel, "The German Palate," Current Literature, July 1901, 67. The piece was widely reprinted. A 1907 printing credits it to Clinton Rogers Hayes. Clinton Rogers Hayes, "German Cookery and the Delicatessen," Cooking Club Magazine 9, no. 3 (1907): 144-45, 153. This anecdote was previously discussed in more detail by the author in Turning the Tables: Restaurants and the Rise of the American Middle Class, 1880-1920 (Chapel Hill: University of North Carolina Press, 2011), 104. 
Today, if at first you do not like a new food, you might nonetheless add it to your shopping list hoping that over time you might "acquire a taste" for it. In the nineteenth century, although it was not unusual to hear people speak of "acquiring a taste" for liquor, literature, poetry, science, or history, it was rare for the expression to be used to describe a growing appreciation for exotic food. Taste, for our culinary predecessors, was inborn and not something easily challenged or changed.

New ideas about dining and taste emerged in the twentieth century, but if we are to understand dining as it was understood in the past, we must recognize that biological imperatives and not sensory tastes were often the most important standard by which Americans decided what to eat. Still, physiology was not the only measure of a good meal; social class also played a significant role.

\section{Class}

Social historians, almost from the start, have viewed food as an important descriptor of class status. In a well-known work from the early days of the Annales School, Jean-Jacque Hémardinquer mapped out the social status of French in the Ancien Régime by cataloging the animals they raised and how they were consumed. ${ }^{34}$ But early works of food history went well beyond counting pigs. In his seminal work on the moral economy, E. P. Thompson discussed how changes in English laws pertaining to grain distribution forced those who felt cheated by the new rules to act collectively in order to demand recognition of disappearing traditional privileges even as the market economy developed. ${ }^{35}$

Generally, these works demonstrate that those with more money have had more access to food and as a result have been freer to make decisions about what they ate and the meanings attached to those foods. In one of the founding works of culinary history, Stephen Mennell showed that the development of culinary rituals in the elite households of Europe was an essential part of the "civilizing process" (a term borrowed from Norbert Elias), a part of the contest between social groups for distinction. A luxurious table was part of what made a king a king. ${ }^{36}$

Americans at the turn of the century were no less aware than their noble counterparts in Europe that food marked class differences and thus class, like physiology, helps to explain what Americans valued when they sat down at the table. Taste mattered, but it was taste as fashion rather than taste as fla-

34. Jean-Jacques Hémardinquer, "The Family Pig of the Ancien Régime: Myth or Fact?” in Food and Drink in History: Selections from Annales, ed. Robert Forster and Orest Ranum (Baltimore: Johns Hopkins University Press, 1979), 5: 50-72.

35. E. P. Thompson, "The Moral Economy of the English Crowd in the Eighteenth Century," Past and Present 50, no. 1 (1971): 76-136.

36. Stephen Mennell, All Manners of Food (Oxford: Basil Blackwell, 1985). 
vor, that determined what well-drilled waiters in crisp tuxedos laid before the titans of American society when they dined at the Waldorf-Astoria.

In the late nineteenth century, wealthy Americans were feeling their oats, as it were. The United States had quickly risen from an emerging industrial power to the dominant industrial power in the world, and in an economy with few regulations, economic success - whether it came from founding a steel mill or owning some valuable land in Manhattan —was amply rewarded. But wealthy Americans were not satisfied with mere wealth; they also wanted social recognition, and they, like those French kings, often sought that respect by consuming course after course of "chapon à la Bressoise" and "grouse sauce au pain." ${ }^{37}$ The American elite celebrated French food as the world's best cuisine, and not only went to restaurants that served American imitations of upper-class French cuisine, but also (starting with August Belmont in 1857) hired chefs from France to staff the kitchens of their mansions. ${ }^{38}$

French cuisine, with its own grandiose language and elaborate rituals of production, demonstrated the American upper class's ability to consume conspicuously in ways similar to their European counterparts. American elites might not be able to claim ancestral titles (although they married their daughters to European aristocrats in order to brag that they had a duke or a baron in the family), but they could eat the way they imagined English and Hungarian aristocrats dined. This "upper-crust" affectation (a turn of phrase that has more to do with hats than bread) announced to the world that America's aristocracy of wealth deserved their title.

Yet, even if they looked to Europe as the measure of their success, America's wealthy were Americans and there was awkwardness about their Europhilia that shifted from the philosophical to the real when a late nineteenthcentury American found himself suffering from an upset stomach. In the post-Civil War era, culinary magazines and newspaper articles, echoing the belly aching of the rich, lamented the gustatory consequences of wealth. Upper-class Americans, the typical account observed, were forced to dine out at expensive restaurants and attend ceaseless parties in order to preserve their social standing. At these gatherings, the rich French food was designed to show off status, not to maximize health, and a consequence of such overindulgence was often a tummy ache. If newspaper and magazines reports were to be believed, the wealthier you were, the sicker you were. Suffering from ceaseless (although vague) gastronomical illnesses, it seems that that when they were not dining out in public, American aristocrats were often reduced — or at least claimed they were reduced — to eating plain biscuits with sherry. ${ }^{39}$ These complaints were so common, and so routinely reported on, that dyspepsia became known as the "American disease."

37. Menu, "Military Order, Loyal Legion, United States," Delmonico's, New York, N.Y., December 2, 1896. In author's possession.

38. Eric Homberger, Mrs. Astor's New York: Money and Social Power in a Gilded Age (New Haven: Yale University Press, 2004), 176.

39. "German Restaurants," New York Times, January 19, 1873, 5. 


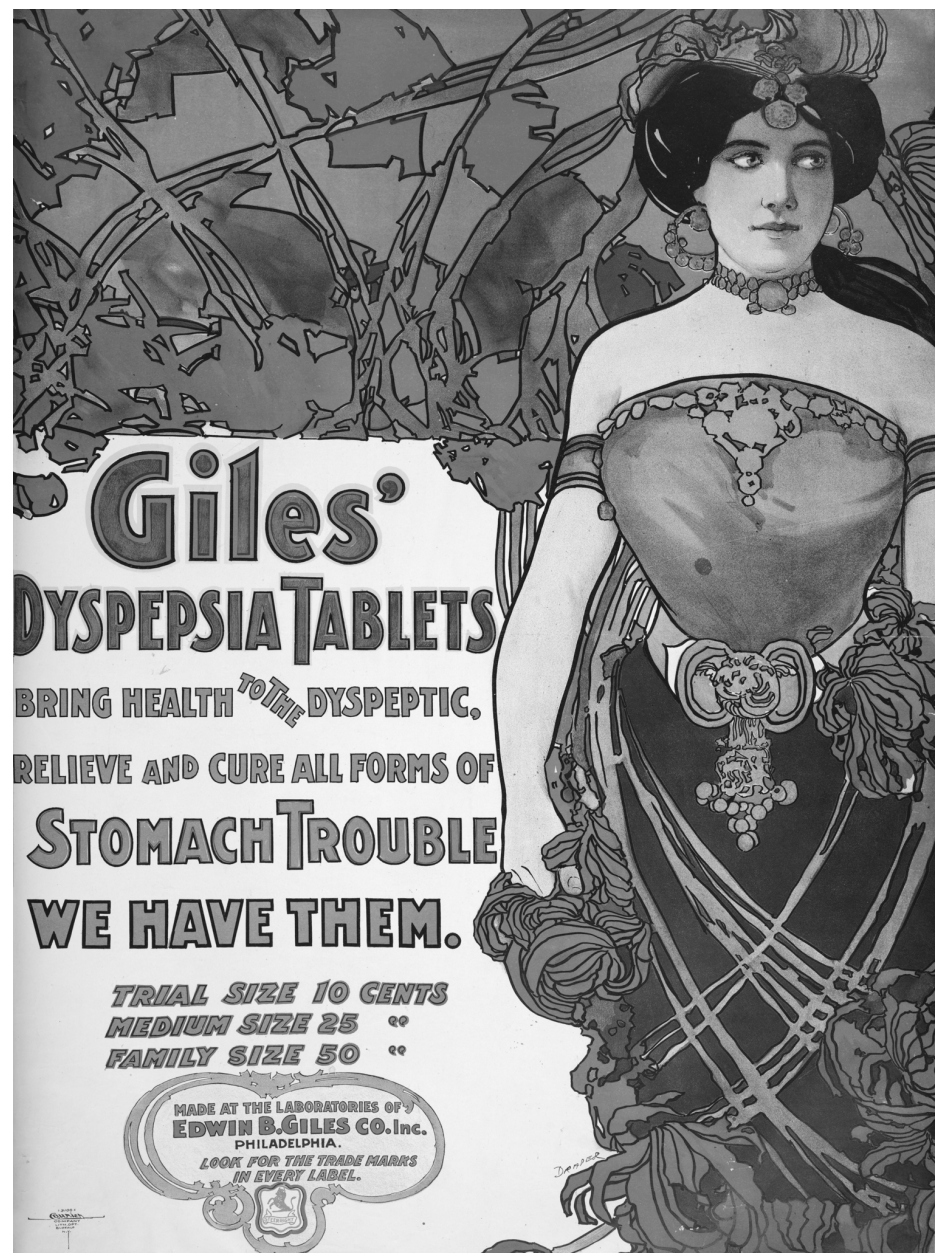

Commercial poster for Giles' dyspepsia tablets (1895-1917). (Courtesy of the Stephen A. Schwarzman Building/Art and Architecture Collection at the New York Public Library)

Persistent dyspepsia fueled wealthy Americans' fascination with dietary cures, including their patronage of the Battle Creek Sanitarium run by internationally renowned doctor and dietician, John Harvey Kellogg. It fueled an interest in fad diets and articles on how frugally American's richest men ate when outside the public spotlight. ${ }^{40}$ Most importantly, it provided a cultural narrative of deprivation that balanced the scenes of orgiastic culinary extravagance that routinely filled society columns. Complaining about the effect of too much money on your health not only reminded everyone that you

40. See, for example, “'Bread and Milk' for Society,” The Caterer 11, no. 3 (1900): 34. 
had too much money, but it was also a shrewd thing to do in a country whose founding tales were not about aristocratic luxury but Puritan work. In a cartoon published in the New York Times in 1913, two men look longingly through the front window of a restaurant. One, dressed as if indigent, can't afford to eat in the restaurant. The other, in top hat and white tie, suffers from a stomach debilitated by years of luxurious eating and is now, like the homeless fellow, reduced to staring through the window at food he is unable to enjoy. ${ }^{41}$

America's wealthiest aristocrats shared the national belief that what they ate was a reflection of who they were. This biological and social imperative was, in part, the reason they ate French food and consumed only the choicest steaks. As Dr. Steven Smith Burt, the house doctor at the stately Astor Hotel, told a reporter for the New York Times in 1905, the fine-grained steaks that the hotel served its upper-class patrons could not be properly digested by a man who did physical labor. ${ }^{42}$ But wealthy Americans' obsessive complaining about the dietary costs of their extravagant lifestyles suggests that even if they respected biological imperatives, they also knew the importance of crafting a politic story, one that emphasized the cost of the good life. This was not new. Bourgeois diners in pre-Revolution France consumed bowls of broth generally reserved for the sick in order to demonstrate that the sensibilities of the middle class were more refined than those of the working class. ${ }^{43}$ Likewise, Southern women living on plantation estates convinced doctors to prescribe opiates and then took to their beds in a dramatic effort to manifest the strains of running a household (albeit, one where the physical work was done by slaves and later servants). ${ }^{44}$ But in the late nineteenth century, as labor unrest and the specter of class warfare loomed large in newspaper headlines, a little bellyaching helped to sustain a delicate balance between distinction and democracy.

What our ancestors ate can tell us a lot, but the stories our predecessors wove about what they ate must be every bit as prominent as the food itself when we recount the history of dining in America. This fact, once again, poses challenges for the historian and the curator, for the French menu is easier to digest than the indigestion that followed. But together, we can find ways to demonstrate to the public that food is more than what it seems. And when we do, accounting for ideas about gender will be as important as tales of physiology or class.

\section{Gender}

A part of this story is familiar to anyone who has looked at the historical role of women in America. Women were viewed as nurturers, a job that in-

41. "The Romance and Reality of New York's Restaurants," New York Times, November 23, 1913.

42. William Griffith, "The New Yorker and His Dinner," New York Times, March 26, 1905.

43. Rebecca L. Spang, The Invention of the Restaurant: Paris and Modern Gastronomic Culture (Cambridge: Harvard University Press, 2000), 39-41.

44. John Burnham, Bad Habits (New York: New York University Press, 1993), 114-15. 
volved not only childbirth but also maintaining a Christian home. Advice columnists and domestic manuals, often following the lead of the early nineteenthcentury domestic doyen, Catharine Beecher, constructed rules and guidelines for female homemakers designed to insure tranquility and morality in the home. Cooking was an essential part of creating that domestic harmony. In The American Woman's Home published in 1869, Beecher wrote, “There are but a few things on which health and happiness depend more than on the manner in which food is cooked. You may make houses enchantingly beautiful, hang them with pictures, have them clean and airy and convenient; but if the stomach is fed with sour bread and burnt meats, it will raise such rebellions that the eyes will see no beauty anywhere."45

Women would not be contained in the home, however, and throughout the nineteenth century, they sought a larger role in public affairs. Then a curious thing happened. While cultural authorities had been happy to entrust women with the family's domestic diet, they were deeply suspicious of women's ability to make good food choices when eating in public. So when women entered the public sphere and sought to take advantage of the convenience of cheap restaurants, even in dining halls that were gender segregated, female diners were viewed with distrust. In the late nineteenth century, women were routinely lambasted for their poor eating habits, especially their alleged penchant for ice cream, candies, lobster, and a host of other "unhealthy" foods_-including salads. ${ }^{46}$ An article in the Washington Post in 1896 claimed that "waiters stand aghast at her selections from the bill of fare, and so do men, for the average woman's luncheon offends every gastronomic principle." 47

Despite these misgivings, by the beginning of the twentieth century, as more and more American women entered public life as shoppers, reformers, and politicos, they earned men's grudging respect. Some men, like the New York restaurateur Louis Sherry, surrendered their prejudices with grace and declared these women fit for public life. ${ }^{48}$ Others came around with a bit more difficulty. Examining how these men thought about food and gender offers insight into the deep challenges to traditional roles for both men and women that were taking place at the turn of the century. Here, once again, it is not the recipe but the repercussions that matter.

In September 1901, the popular turn-of-the-century culinary magazine What to Eat published a confessional article titled "Is It Manly to Eat Salads?" At first glance, the article appears to be the historical precursor of the tonguein-cheek parody of changing gender roles from 1982, Real Men Don't Each

45. Catharine E. Beecher, The American Woman's Home: Or, Principles Of Domestic Science; Being A Guide To The Formation And Maintenance Of Economical, Healthful, Beautiful, And Christian Homes (New York: J.B. Ford and Company, 1869), 83.

46. Helen Car, "Good Living and Good Looks," What to Eat, October 1897, 80.

47. "Ladies Fair at Lunch," Washington Post, December 13, 1896; Edna G. Howard Shertzer. "On Ordering Luncheon." What to Eat, September 1902, 129.

48. "The Maid and the Menu: Can a Woman Order a Dinner?" New York Times, October 30, 1904. 
Quiche. Just as eating quiche came to represent men who were willing to embrace second-wave feminism, eating salads signaled the progressive fin de siècle man's growing comfort with first-wave feminism and the emerging women's rights movement. The anonymous author observed that the "average man of robust habit has always relegated salads to the category of feminine flim-flams - mere culinary conceits of the finical and pampered epicures, who give little thought to the efforts of such combinations upon the interior department." 'But he conceded that his bias was dated. Research had demonstrated that eating lightly could be healthy and that it was men, not women, who needed to adjust their diets. "Even men are progressing gastronomically. Scientific dietetics has at last revealed to us the fact that the woman who eats salad on a hot day in July, August or September, is displaying sound, gastronomic sense." 49

The self-congratulatory tone that the unnamed author adopts about this culinary awakening implies that the transition to the era of healthy eating happened without a hitch. But eating is intimate, and the transformation that gender roles in the United States had undergone was dramatic. As the article's author makes clear in his retelling of an incident that happened "several years ago," the change from viewing food as "character" to food as "nutrition" involved a fundamental remapping of what constituted both manliness and taste.

We remember to have seen what we then regarded as a feminine man, seat himself at a table in a restaurant, one hot day in July, several years ago. We noticed that he wore several rings on the fingers of both hands, that the hands bore evidence of being innocent of toil, and that the lines of his face were impressively effeminate. He was what would be called in curb-stone vernacular, a Willie-boy. There was no doubt about that. We were curious to know what the Willie-boy would order for his repast. .. . Our curiosity was soon gratified by seeing the waiter place in front of him a dish of salad and a half-dozen "lady-fingers." As we watched his lily-white hands manipulate this "repast," our astonishment gradually changed to indignation, and we made up our mind that a large section of lead-pipe would be the proper remedy for a gastronomic freak of this kind. ${ }^{50}$

This recollection of "one hot day in July" is shocking not only because the author unabashedly advocates violence, but also due to the source of his murderous impulse. He does not direct his anger at the "effeminate" man because he is a "Willie-boy," but rather because he is a "gastronomic freak." It is the effeminate man's performance of gender, publicly eating phallic ladyfingers and feminine salads, that arouses rage.

Modern science, flawed as it may have been, was remapping ideas about both sexuality and food. The turn of the twentieth century saw the invention of both the scientific label "homosexual" and the discovery of calories. ${ }^{51}$

49. "Is it Manly to Eat Salads?" What to Eat, September 1901, 117.

50. "Is it Manly to Eat Salads?" 117.

51. George Chauncey, "From Sexual Inversion to Homosexuality," in Kathy Peiss and Christina Simmons, eds. Passion \& Power: Sexuality in History (Philadelphia: Temple University 
Aware of these changes, the author of "Is It Manly to Eat Salads?" has revised his early prejudices and has come to see that "it is not a sign of mental decay or moral degeneracy for a man to eat salad; it is gastronomic sense." But the author's anger toward the salad-eating "gastronomic freak" and his previous unwillingness to eat salads can only be understood in the context of the older "science" that held that the foods you ate were biologically linked to your gender.

My point is not to hold up for ridicule a previous generation's naive ideas about nutrition but rather to force us to think more thoroughly about the complexity of their beliefs about food. If we want to understand the past, we need to be fully versed in and sympathetic to their understanding of diet.

\section{Meeting Expectations}

When describing a nation where taste did not solely or significantly determine what people ate, addressing issues of context-physiology, econom ics, and gender, among many possible explanatory frameworks - can go far to replace nostalgia and triumphalism with historical insight, but we must also admit that there are times when the complexities of food defy easy explanation. Understanding the social milieu cannot reveal all the subtle and contradictory motives that shaped our culinary experiences.

The history of Chinese food in America-and chop suey, in particularhad already been undertaken when I began my own study of the subject ten years ago, and it has been reconsidered many times since. ${ }^{52}$ Still, despite all the scholarship, mysteries remain, and until we can provide more definitive answers to why Chinese food was so popular at the turn of the twentieth century, we must be careful that we do not allow the sketchy historical record to be filled with simplistic ideas about American progress and racial tolerance.

At the turn of the century, Americans fell in love with chop suey. The origins of chop suey are much debated. The dish-composed of various chopped meats, leftover vegetables and noodles - was (and is) often attributed to early Chinese immigrants to the United States who threw together the popular dish for railroad laborers. But as the anthropologist E. N. Anderson has demonstrated, it probably had its origin in the Toisan province of China, a rural area south of Canton from which a disproportionate number of Chinese migrated to the United States. ${ }^{53}$

Press, 1989), 87-117; Hillel Schwartz, Never Satisfied: A Cultural History of Diets, Fantasies, and Fat (New York: Free Press, 1986); Levenstein, Revolution at the Table; Sarah Abigail Leavitt, From Catharine Beecher to Martha Stewart: A Cultural History of Domestic Advice (Chapel Hill: University of North Carolina Press, 2002).

52. See, for example, Andrew Coe, Chop Suey: A Cultural History of Chinese Food in America (Oxford: Oxford University Press, 2009); Samantha Barbas, “'I'll Take Chop Suey’: Restaurants as Agents of Culinary and Cultural Change,” Journal of Popular Culture 36, no. 4 (2003): 669-84.

53. E. N. Anderson, The Food of China (New Haven: Yale University Press, 1988), 174. 
Regardless of its origins, chop suey was discovered by middle class "slummers" (probably in San Francisco) in the late nineteenth century, and in the dawning days of the new century, San Franciscans, Los Angelenos, New Yorkers, Chicagoans, Washingtonians, Pittsburghers, and a host of other urbanites with access to local Chinatowns frequented Chinese restaurants en masse in order to secure the inexpensive dish. "FAD FOR CHINESE FOOD," screamed a headline in the July 21, 1901, Washington Post and, in 1902, What to Eat reported that "[t]he chop suey fad has struck New York society, and this national dish of the Chinese now appears on the menu of many a fashionable dinner in a private house, to say nothing of those in big hotels and clubs." ${ }^{54}$ Soon, chop suey was more popular with Americans than with the Chinese. As Sunyowe Pang told readers of the Forum in 1902: "Chop sooy is made to sell to curious white persons who visit Chinatown." 55

For more than ten years, chop suey was America's culinary obsession, and the dish fueled the growth of Chinese restaurants across the country. In a March 1910 article for The Steward, a restaurant industry journal published in New York, Fou-Cheou Hi-Kien claimed that the American public's insatiable desire for chop suey was "sufficient to keep open night and day, in flourishing condition, several thousand of such Oriental resorts, throughout the length and breadth of Uncle Sam's domain." ${ }^{.56}$ His estimates are borne out by scholars who have looked at city directories. In Chicago, the number of Chinese restaurants grew from 17 to 122 between 1902 and 1917. ${ }^{57}$ In Los Angeles, there were five Chinese restaurants in the city directory in 1903 and 28 in $1923 .{ }^{58}$ In New York, Jessup Whitehead estimated there were only eight Chinese restaurants in 1889; by 1928, there were 111 in Manhattan alone. ${ }^{59}$ Washington, D.C. boasted a couple of Chinese restaurants when the first "regular first-class Chinese restaurant" catering to Americans opened in 1894; by 1903, the city's many Chinatown restaurants were being promoted as a tourist destination. ${ }^{60}$

The chop suey fad was not only a big city fad. Enterprising Chinese restaurateurs recognized an opportunity and Chinese restaurants serving chop suey began to appear in small cities and large towns-including places that did not boast a recognizable Chinese community. By 1912, one reporter claimed that "From Pell street to the far-flung limits of Harlem, from San Francisco to

54. Margaret Rayburn, "Fads and Fancies of Gotham: Formula for Chop Suey," What to Eat, September 1902, 95.

55. Sunyowe Pang, "The Chinese in America," Forum, January 1907, 605.

56. Fou-Cheou Hi-Kien, "The Celestial Caterer," The Steward, March 1910, 25.

57. Jie Zhang, "Transplanting Identity: A Study of Chinese Immigrants and the Chinese Restaurant Business" (Ph.D. diss., Southern Illinois University at Carbondale, 1998), 127. One estimate appearing in the Los Angeles Times in 1907 placed the number of chop suey restaurants in Chicago at 126. "Will Surprise Chicago," Los Angeles Times, January 28, 1907.

58. J. A. G. Roberts, China to Chinatown: Chinese Food in the West (London: Reaktion Books, 2002), 145 .

59. Jessup Whitehead, The Steward's Handbook (Chicago: J. Anderson, 1889), 379; Louis H. Chu, "The Chinese Restaurants in New York City" (master's thesis, New York University, 1939), 26.

60. "A Dinner in Disguise," Washington Post, October 16, 1894; "Like Oriental Cuisine," Washington Post, November 30, 1902. 


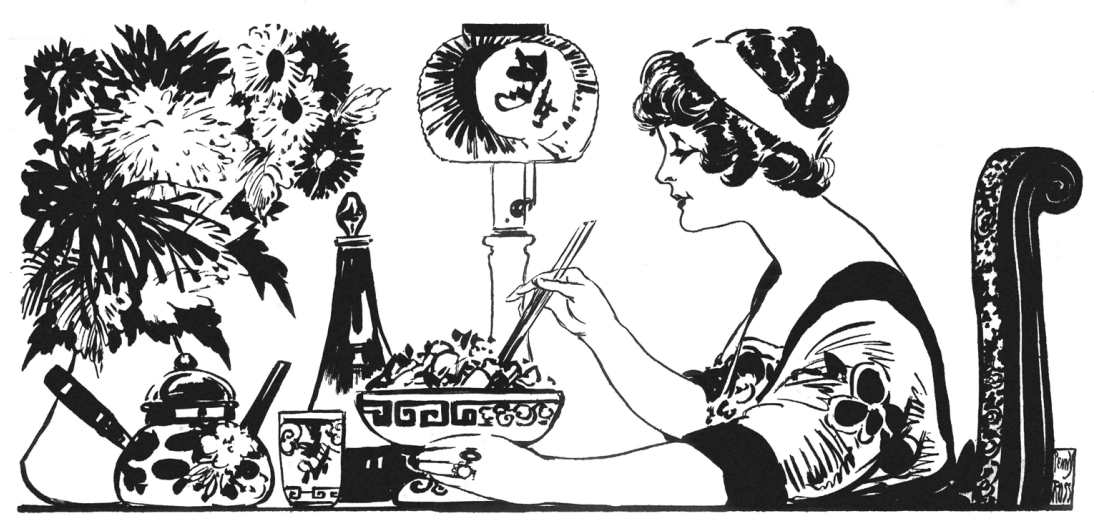

Woman eating homemade chop suey, 1913. (Public domain, from Marion Harland, "Chop Suey and Some Rice Dishes," Los Angeles Times, October 12, 1913, sec. 8, 6)

Sandy Hook, not forgetting way stations, and, in fact in every American town which is big enough to call its main street a gay white way, there are one or more Wing Fungs and Sam Lis who sell chop suey to lovers of the bizarre and Oriental, not to mention to street car conductors on night runs." ${ }^{1}$

Press coverage of the chop suey fad furthered Americans interest in Chinese cuisine. The Washington Post's story announcing the fad noted that while the "ways of the Chinese cooks are strange to American eyes . . . the results cannot be gainsaid" and then recommended that "adventurous" visitors to Chinese restaurants try sturgeon bladders and various moss dishes. ${ }^{62}$ Other articles on chop suey included recipes or discussions of key ingredients. Noting that chop suey "bids fair to become a standard food in this country," the New York Evening Post in 1902 offered its own (somewhat dubious) instructions for making chop suey at home. After cutting the meat and vegetables, the paper instructed, everything should be thrown in a pan and cooked for five minutes. No stickler for tradition, the Post suggested that melted butter or olive oil could substitute for peanut oil, turkey gizzards might replace chicken gizzards, and "Indian soy" could be "imitated" by a teaspoon of Worcestershire sauce and a teaspoon of brown sugar or molasses. ${ }^{63}$ By 1917, the Washington Post was even offering a recipe for "mock chop suey" made with hamburger, paprika and rice. ${ }^{64}$

For at least ten years and probably closer to twenty, chop suey was a national obsession. But what does chop suey tells us about America in the early twentieth century? While a number of well-researched accounts of the popularity of Chinese food in the early twentieth century have been written, none

61. From the New York Telegraph reprinted as "Chop Suey Hoax Exposed," Washington Post, September 29, 1912.

62. "Fad for Chinese Food," Washington Post, July 21, 1901.

63. From the New York Evening Post reprinted as "Chop Suey More Popular," Washington Post, July 27, 1902.

64. “Good Things to Eat,” Washington Post, August 5, 1917. 
of these has offered a definitive answer to the most important question: did eating chop suey sway political attitudes toward the Chinese?

Agitation on the West Coast brought about the passage of the Chinese Exclusion Act of 1882. It effectively closed America's borders to Chinese emigrants for ten years. It was renewed in 1892 by the Geary Act and made permanent in 1902. Chinese government protests and a boycott of American goods in 1905 served to awaken some Americans to the mistreatment of the Chinese that the act had engendered and forced Teddy Roosevelt to rein in the abuses of the Immigration Bureau, but the anti-Chinese immigration law remained in force. In 1924, when the nation passed its first comprehensive immigration act, the policy was continued and the few exemptions that the original series of laws had allowed were eliminated.

How could Americans strengthen their commitment to barring Chinese immigrants at the same time that they were discovering Chinese food and craving hot dishes of chop suey? We think of ourselves as a progressive nation, and generally we have come to view the celebration of ethnic foods as a part of our growing tolerance. Looking back, we want to believe that as Americans became more familiar with new cultures, a process that was facilitated by visiting ethnic restaurants and making Chinese food at home, we shed our prejudices. Even some contemporaries believed that the rush of visitors to Chinatown might result in more lenient immigration laws and for those committed to exclusion, the chop suey craze posed a real threat. Writing in the Chautauquan in 1901, J. Torrey Connor worried that the inevitable effect of tourism in Chinatown, including culinary tourism, would be greater tolerance.

Having seen "Chinatown[,]" the sight-seer, with a superficial knowledge of the "ways that are not our ways," too often doubts not that he knows it all. If questioned as to his views on the economic and moral side of the problem offered by the presence of the Chinese in the United States, he would doubtlessly hold with the sentimentalists, who see in the Chinese a downtrodden, long-suffering people, bearing the yoke of race prejudice. The truth is that the meek, inoffensive, non-resistant Chinaman whom the enthusiasts have pictured, exists chiefly in the imagination and in the decorations on tea-chests. ${ }^{65}$

But Connor's fears were unfounded. If American attitudes toward the Chinese did change, and there is little evidence that they did, new interest in eating Chinese food did not result in less discriminatory immigration laws.

We can speculate about the relationship between Chinese food and Chinese exclusion, and we should. It is possible, for example, that middle-class diners, chop suey's biggest fans, lacked the political clout to have their voices heard on the issue of immigration. Or perhaps, as I suggested above, older ideas about food preferences relating to character were dying, and taste-a sensory judgment rather than a political choice-led people to crave a new culinary sensation without their giving much thought to those who prepared

65. J. Torrey Connor, "A Western View of the Chinese in the United States," Chautauquan, January 1901, 374 . 
it. Or, possibly, restrictions on future immigrants were seen as having little to do with the culinary contributions of Chinese immigrants who had already settled in the United States and were successfully assimilating through restaurant ownership. Certainly, my failure to find satisfactory answers to these questions does not mean there are no answers, and it does not mean we should not share the story of Chinese food's fantastic popularity with the public. However, we must proceed with caution. In the case of chop suey, it is not enough merely to provide the context; instead, we must specifically warn our audience that there are questions that remain unanswered and engage in a dialogue about the intricate links between taste and politics.

I have been studying this issue for years, and I remain puzzled by the failure of most cultural commentators in the early twentieth century to consider the link between chop suey and immigration policy-Connor was a rare exception - and equally puzzled by the lack of attention this question has received from historians. This silence is risky. From Reconstruction-era cartoons depicting immigrants from around the world gathered at "Uncle Sam's Thanksgiving Dinner” to melting-pot allegories, Americans have traditionally associated ethnic assimilation and accommodation with eating. Although this faith in the power of food to transform xenophobes into cosmopolitans often has been more wishful than factual, it continues to shape the way we view the past. If, when confronted with historical questions where the answers are not simple, historians and curators presume the facts will speak for themselves, our audience may fill the void with an overly optimistic, progressive interpretation of history. They will see, as I wish I could, more discrimination in taste and less discrimination in social relations than the historical record will support. ${ }^{66}$

\section{Conclusion}

Historians know that the "truth" about the past is rarely simple, but communicating that truth is especially difficult when the subject is food because we have so often used food to smooth over the imperfections in our national story. In the late nineteenth century, the colonial revival sought to celebrate the simple foods of the founding generation as a remedy to the rapid rate of industrialization and increased immigration. ${ }^{67}$ In the early twentieth century, restaurateurs claimed technological advancements in food service would eliminate economic inequalities. ${ }^{68}$ In the late twentieth century, we celebrated our culinary diversity in the hope that overcoming racial and ethnic tensions

66. The best treatment of these complex issues, although not a history, was penned by Lisa Heldke. Lisa M. Heldke, Exotic Appetites: Ruminations of a Food Adventurer (New York: Routledge, 2003).

67. Katherine L. Turner, "Learning to Love Pilgrim Succotash: Food Reform and the Colonial Revival in America, 1875-1925" (conference paper, American Historical Association 123rd Annual Meeting, New York, January 3, 2009).

68. See, for example, "Another Step Forward in Social Evolution," The Caterer 12, no. 6 (1902), 13-14 
might be as easy as learning to like collard greens and gefilte fish. Today, we watch cooking shows and imagine they offer simple answers to the challenges of running a home where there are two full-time wage earners.

Historians of all stripes have confronted the challenge of communicating the complexity of history and addressing historical myths before, but with food, it is not just our minds that play tricks with us, but also our bodies. Food is familiar and history often is not. Like kids at the candy store window, we can almost taste the past. Thus we must be especially careful when thinking about food and presenting culinary history to the public. Painstakingly restoring a kitchen, whether it is Julia Child's in the Smithsonian or the everyday kitchens found in countless other museums, provides a valuable material reminder of how we lived, but it also creates a deceptively ahistorical space that wemyself included - are all too eager to populate with sentimentalized, imagined lives.$^{69}$ If visitors to these historical kitchens are not carefully guided, they will not imagine the monotony of standing over hot pots, the greasy stews and stringy meats that served as dinner, or the secret pleasure of the domestic servant who knew his wealthy employer had been reduced to eating dry biscuits. Historians need to make these spaces specific, filling them with the complex and nuanced stories that historical actors told (and sometimes did not tell) about themselves while banishing mythic tales of culinary conquest to works of folklore. The historical profession has done this well in the past, championing the stories of everyman laborers and common soldiers, and I believe we can do the same for cooks, but we must be vigilant.

\begin{abstract}
ANDREW P. HALEY is an associate professor of American cultural history at the University of Southern Mississippi who studies class and consumption in the Gilded Age and Progressive Era. He has a Ph.D. from the University of Pittsburgh. In his first book, Turning the Tables: Restaurants and the Rise of the Middle Class (UNC Press, 2011), he examines how struggles with elites over public dining shaped the American middle class in the late nineteenth and early twentieth centuries. Currently he is working on a book that examines the history of children and dining in the United States. He has worked with the Hattiesburg, Mississippi, historical society to help preserve photograph collections, has consulted on museum exhibits and historical recreations of public dinners, and once spent a marvelous summer as a tour guide at the Old North Church in Boston's North End.

I am grateful for support and advice from The Public Historian, especially editor Randy Bergstrom and special features editor Kristin Ahlberg, and from the excellent and anonymous reviewers they secured for this essay. I have also received invaluable assistance from Amy Milne-Smith and Danielle Sypher-Haley. That does not mean, of course, that they agree with everything I have written.
\end{abstract}

69. Julia Child's kitchen was temporarily closed in early 2012. It will reopen late in the summer of 2012 as part of a new exhibit that focuses on food and wine in America. Incorporating Julia's kitchen in the larger story of American culinary history may help to address some of the issues raised by this essay. For more on the temporary closing of the Child exhibit, see "Bon Appétit! Julia Child's Kitchen at the Smithsonian," National Museum of American History, Smithsonian, http://americanhistory.si.edu/exhibitions/exhibition.cfm?key=38\&exkey=59 (accessed May 2012). 